
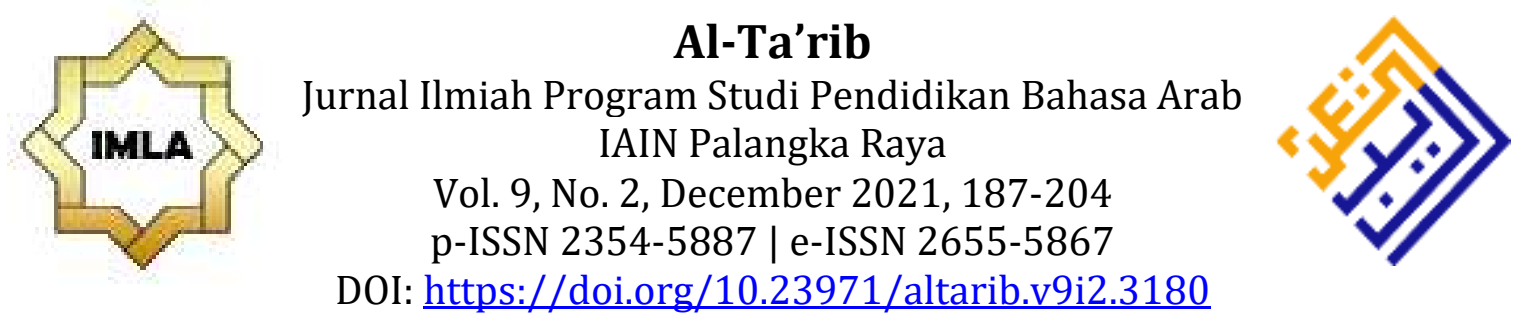

\title{
CORONA IN THE POET'S PERSPECTIVE: A COMPARATIVE LITERATURE STUDY OF THE POETRY "BUBARNYA AGAMA" AND "SYUKRĀN KURŪNĀ"
}

\author{
Ahmad Hizkil1, Mukhotob Hamzah ${ }^{2}$, Tatik Mariyatut Tasnimah ${ }^{3}$ \\ 1,2,3 Universitas Islam Negeri Sunan Kalijaga, Yogyakarta, Indonesia \\ E-mail: ahmadhizkil1996@gmail.com
}

\begin{abstract}
This study aims to analyze the message of two poems about the Coronavirus pandemic, namely "Bubarnya Agama" and "Syukrān Kurūnā," and reveal the similarities and differences between them the two poems based on their intrinsic and extrinsic elements. This study uses a qualitative method that uses a comparative literature approach. The data collection technique used is the reading, and notetaking technique, namely the author reads carefully and deeply and then notes the important things from the two poems. Meanwhile, the data analysis technique is descriptive-comparative, which describes the intrinsic and extrinsic elements of the two poems and then compares them. The messages contained in the two poems are generated from the results of the meaning and comparison of the elements of the two poems. This study indicates that the poem "Bubarnya Agama" by Said Muniruddin from Indonesia and the poem "Syukrān Kurūnā" by Jabeer Ali Ba'adany from Yemen are two poems that have their characteristics in terms of their intrinsic and extrinsic elements. The two poems are a response from two poets from different countries to the Coronavirus pandemic hitting all parts of the world. Both poets have their perspectives in interpreting the coronavirus pandemic. However, the two poets both see Corona as something that brings wisdom and major changes to humanity's living and religious order.
\end{abstract}

Keywords: Arabic poetry, comparative Literature, Corona, Indonesian poetry, poet

\section{Abstrak}

Penelitian ini bertujuan untuk menganalisis pesan dari dua puisi tentang pandemi virus Corona yakni puisi "Bubarnya Agama" dan "Syukrān Kurūnā" dan mengungkap persamaan dan perbedaan kedua puisi tersebut berdasarkan unsur intrinsik dan ekstrinsiknya. Penelitian ini menggunakan metode kualitatif dengan menggunakan pendekatan sastra bandingan. Adapun teknik pengumpulan data yang digunakan adalah teknik baca dan catat yaitu penulis membaca secara teliti dan mendalam kemudian mencatat hal-hal penting dari kedua puisi tersebut. Sedangkan untuk teknik analisis datanya adalah deskriptif-komparatif yakni memaparkan unsur intrinsik dan ekstrinsik kedua puisi kemudian 
membandingkannya. Pesan yang terkandung dalam kedua puisi dihasilkan dari hasil pemaknaan dan perbandingan unsur keduanya. Hasil penelitian ini menunjukkan bahwa puisi "Bubarnya Agama" karya Said Muniruddin asal Indonesia dan puisi "Syukrān Kurūnā" karya Jabeer Ali Ba'adany asal Yaman adalah dua puisi yang memiliki ciri khas tersendiri dari segi unsur intrinsik dan ekstrinsiknya. Kedua puisi tersebut merupakan respon dua penyair berbeda nagara terhadap pandemi virus Corona yang sedang melanda seluruh belahan dunia. Kedua penyair memiliki cara pandang tersendiri dalam memaknai pandemi virus corona tersebut. Meski demikian, kedua penyair sama-sama melihat Corona sebagai sesuatu yang membawa hikmah dan perubahan besar terhadap tatanan berkehidupan dan berkeagamaan umat manusia.

Kata Kunci: Corona, penyair, puisi Indonesia, syair Arab, sastra bandingan

\section{INTRODUCTION}

Historically, pandemic disasters are not a new thing in human life. For example, in 1346-1352 AD, a terrible pandemic in the European region spread to the Middle East region, namely the Black Death pandemic (Rahmani 2010:3). Long before that, at Abu Bakr and his companions, precisely in 638-639 AD, there was an 'Amway epidemic that attacked Syria and spread to Egypt and Iraq (Hilmy and Niam 2020:296). The terrible and terrible history of these plagues can be read in historical literature and can often be found in the compositions of the poets of that period. For example, during the Black Death pandemic in 1346-1352 AD, a poet from Syria, Ibnul Wardi wrote a poem titled Risālatu al-Naba 'An al-Waba,' which describes the ferocity of the Black Death pandemic like a wild animal that can pounce on everyone. The poem stores historical facts about the condition of the pandemic at that time. This further emphasizes that a literary work is nothing but a reflection of the social life of society at the time the literary work was created.

"Earth is sick," perhaps this sentence represents the current state of the world. Almost all countries worldwide are busy with the Coronavirus pandemic that hit. In the first three months alone, since its emergence in early 2020, this virus has infected more than 1.3 million people worldwide and killed hundreds of thousands of people. This has forced several countries to impose "lockdowns" to prevent the spread of the Coronavirus. Lockdown is the closure of access in an area, both entry, and exit.

The Coronavirus pandemic has significantly impacted all aspects of human life. The presence of the Coronavirus that has hit the whole world has made all parties try to present a role, including writers, especially poets. The Coronavirus pandemic has become a magnet for poets worldwide to write various touching poems, igniting the spirit of optimism and not pessimism in the face of world conditions that are not good. Poetry is a weapon for a poet in responding and documenting the events around him. Poetry is also believed to contain the religious values of its author (Pribadi 2011:199).

One of the poems by a poet from Indonesia with the theme of the Coronavirus pandemic that caught the author's attention was the poem "Bubarnya Agama" by Said Muniruddin, a writer, religious scholar, and author of various religious encyclopedias from Aceh. The poem "Bubarnya Agama" is listed on his website, which he wrote on March 16, 2020. This poem is of interest to the author 
because of its unique title and invites a question mark: What is meant by the dissolution of religion in the poem's title? Is the Coronavirus pandemic dissolving religion or what? So this requires an in-depth reading of the poem.

Then if traced to other parts of the world, it turns out that there are not many poems similar to this poem. Poets in other parts of the world compete in pouring their hearts and minds into responding to the ongoing global pandemic. One of them that caught the writer's attention was a poem from a Yemeni poet, Jabber Ali Ba'adany, entitled "Syukrān Kurūnā" which in Indonesian means "Thank you Corona." He wrote this poem on his Twitter account on March 15, 2020. The title of this poem seems to contradict the reality of the ferocity of the Coronavirus, which has claimed many lives. When all people in all parts of the world are haunted by this hidden enemy and strive to kill him, the poet is grateful to him, but it is not poetry if the title is mediocre. A unique and even controversial title will trigger the reader to wonder and find its meaning. The poet Jabeer Ali Ba'adany behind the title of his poem certainly leaves a message and conveys its meaning in the composition of his poetry.

The two poems from the two poets from different countries above (Indonesia and Yemen) have a common theme. Namely, they both talk about the Coronavirus pandemic even though they come from different countries and languages. The similarity in theme and differences in country and language make the writer interested in analyzing the similarities and differences between the two poems more deeply, considering that every poet has their their way of presenting something. The difference in origin of the two poets will allow them to present their poetry based on how they feel and reflect the conditions in their respective countries.

According to Hosilos, one of the important concepts in Comparative Literature is that Comparative Literature examines the comparison between literary works of one author with other authors who live in two different countries (Hosillos 2001:28) so that the discussion of Comparative Literature studies requires discussion of the relationship between two national or international literature. More, or the relationship of certain national literature with civilizations of other nations (Tasnimah 2010:3).

The beginning of the emergence of Comparative Literature was in France, between the late 19th century and towards the middle of the 20th century (Hilal 2003:14). Arabic Literature uses the term al-Adāb al-Muqãran as the equivalent of literature compared to French or Comparative Literature in English (Thahhan 1972:8). Regarding the international aspect of comparative literature study, Van Tiegem distinguishes it from general literature. Comparative literature only examines the relationship between two national kinds of literature, while General Literature examines the connection between several national kinds of literature (Nada 1980:20).

There are two main streams in literature: the French flow and the American flow. The French school emphasizes detailed historical studies around the influence of one author on other authors or the relationship between writers and different regions. In contrast, the American school believes that comparative studies are possible even though there is no influence or influence between the authors being compared. Exert influence. The French school also requires a 
language difference between the two national kinds of literature compared, while the American school does not (Sarhan 1983:12). The American school that emerged later was more complementary to the limitations of understanding and studies pioneered by the French school so that the American school was more broad and flexible in its study (Hassan 1983:14).

There has been quite a lot of research in the scope of Comparative Literature studies. However, the author has not found the Comparative Literature study of poems with the theme of the Coronavirus pandemic, including the two poems that are the object of this research, which have never been studied. It could be because this poem is still relatively new. After all, both were written in March 2020. The two poets who wrote it are also considered modern poets. Nevertheless, a study of plague-themed poetry, one of which can be seen from the research of Raid Abdu al-Rahim (2010) entitled "Risalatu al-Naba 'an al-waba' lizainiddin ibn al-wardi (dirāsah naqdiyyah)." This study tries to analyze Ibnul Wardi's poem, Risālatu An-Naba 'an al-waba,' which Ibnul Wardi wrote two days before he died due to the Black Death pandemic that hit Aleppo in 1349 AD.

Meanwhile, research that discusses poetry with the theme of the Covid-19 pandemic include: First, research from Elyusra (2020) entitled "Estetika dan Makna dalam Puisi "Untuk Corona tanpa Mengeluh" karya Salami dan Implikasinya terhadap Pembelajaran di Sekolah". Second, research from Herwan (2021) with the title "Citraan Metafor pada Puisi Tema Covid-19 Karya Anak Sekolah Dasar". Third, research by John Guruh Nivak (2021) with the title "Moralitas dalam PuisiPuisi Bertopik Covid-19: Literary Philosophy Approach (Immanuel Kant's Ethical Philosophy)". Another research that is also similar but with a different object is the research of Andriyani (2021) with the title "Wabah Corona dan Unggahan di Instagram: Analisis Komponen Tindak Tutur".

Judging from the several studies above, the research in the scope of Comparative Literature with the object of poetry with the theme of the Covid-19 pandemic was not found. Therefore, this research is expected to fill the void and contribute to the study of Comparative Literature and contribute to the moral conception of the ongoing Coronavirus pandemic through the meaning of poetry. With two poems from authors from different countries, it is hoped to enrich the moral conception.

In this study, a comparison will be made between the poem "The Dissolution of Religion" and the poem "Syukrān Kurūnā." The comparison will be based on the opinion of Hutomo (1993, 11-12), which outlines the field of Comparative Literature studies on three things, namely: (1) Affinity, namely the relationship between the intrinsic elements of literary works, (2) Tradition, namely elements related to the history of creation. Literary works, (3) Influence, namely the influence of work by other things outside it. Looking at the objectives and objects of study in this research, the writer only takes two of the three aspects above, namely the Affinity and Tradition aspects, because the two poems studied have a relationship in these two aspects. At the same time, the aspect of influence cannot be applied because the two poems were born simultaneously. 


\title{
METHOD
}

This research is included in library research because the data analyzed are from library work. The method used is qualitative, which utilizes ways of interpretation by presenting it in the form of a description (Ratna 2015:46).

The approach used in the Comparative Literature approach to examine the similarities and differences in the intrinsic, extrinsic, and message elements contained in the two poems. Intrinsic elements include theme, diction, rhyme, tone and atmosphere, the figure of speech, and mandate, while extrinsic elements include the author's biography and social background. This research is more oriented towards American Comparative Literature, which in its study is more flexible and does not require an aspect of influence between works.

The technique used in data collection is the reading, and note-taking technique, namely the author reads carefully and deeply and then notes the important things from the two poems. As for the data analysis technique, the writer uses descriptive-comparative, which describes the intrinsic and extrinsic elements of the two poems and then compares them. The messages contained in the two poems are generated from the results of the meaning and comparison of the two elements. The content decomposition and comparison are based on two things, namely affinity (intrinsic element) and tradition (extrinsic element).

\section{RESULT AND DISCUSSION}

\section{Analysis of "Bubarnya Agama” Poem By Said Muniruddin}

Poetry is a form of literary work presented with beautiful and meaningful words. Compared to other forms of literature, poetry is one of the oldest literary works (Wahyuni in German 2019: 333-34). The poem "Bubarnya Agama" was written by Said Muniruddin, a religious scholar from Aceh, Indonesia. His works have a lot of religious themes, especially Sufism. The following is the poem "Bubarnya Agama" which he wrote on his website on March 16, 2020.

\section{BUBARNYA AGAMA \\ By: Said Muniruddin}

\author{
Makkah sepi \\ Madinah sunyi \\ Kakbah dipagari \\ Masjid tutup \\ Jamaah bubar \\ Jumat batal \\ Umrah distop \\ Haji tak pasti \\ Lafadz adzan berubah \\ Salaman dihindari \\ Corona datang \\ Seolah-olah membawa pesan \\ Ritual itu rapuh! \\ Ketika Corona datang
}


Engkau dipaksa mencari Tuhan

Bukan di tembok Kakbah

Bukan di dalam masjid

Bukan di mimbar khutbah

Bukan dalam thawaf

Bukan pada panggilan azan

Bukan dalam shalat jamaah

Bukan dengan jabat tangan

Melainkan,

Pada keterisolasianmu

Pada mulutmu yang terkunci

Pada hakikat yang tersembunyi

Corona mengajarimu,

Tuhan itu bukan (melulu) pada keramaian

Tuhan itu bukan (melulu) pada syariat

Tuhan itu ada pada jalan keterputusanmu

Dengan dunia yang berpenyakit

Corona memurnikan agama

Bahwa tak ada yang boleh tersisa

Kecuali Tuhan itu sendiri!

Temukan Dia

\section{THE DESTRUCTION OF RELIGION}

\section{By: Said Muniruddin}

Mecca is quiet

Medina is silent

The Kaaba is fenced

Mosque closed

Congregation disbanded

Friday cancel

Umrah stopped

Hajj is uncertain

The call to prayer has changed

Greetings avoided

Corona is coming

As if carrying a message

Rituals are fragile!

When Corona comes

You are forced to seek God

Not on the walls of the Kaaba

Not in the mosque

Not on the pulpit of the sermon

Not in tawaf

Not on the call to prayer

Not in congregational prayer

Not with a handshake 


\author{
But, \\ In your isolation \\ In your locked mouth \\ In the hidden essence \\ Corona teaches you, \\ God is not (only) in the crowd \\ God is not (only) on the Shari'a \\ God is on your path \\ With a diseased world \\ Corona purifies religion \\ That there's nothing left \\ Except for God Himself! \\ Find Him
}

\title{
Affinity Aspect/Intrinsic Element
}

As previously explained, Affinity analysis is an analysis of the intrinsic elements or internal elements of a literary work, which is poetry. The intrinsic elements that the writer examines in this affinity aspect are limited to the theme, diction, rhyme, tone and atmosphere, the figure of speech, and mandate. The following is an analysis of the intrinsic elements of Said Muniruddin's poem "Bubarnya Agama."

\section{Topic}

Themes are the author's ideas, ideas, or views conveyed in a literary work (Fananie 2011:84). In other words, the theme is the main idea representing the entire poem's content. The poem "Bubarnya Agama" generally describes the impact of the Coronavirus pandemic on human religious activities, especially Muslims. However, the impact of these religious activities purifies religion because God as a form of representation sought in worship can exist anywhere and anytime. Therefore, according to the writer's opinion, the theme of this poem is divinity because by studying this poem, one will reach true piety to Allah by contemplating His power. This divinity theme is reflected in the dominance of the word "God" in the poem.

\section{Diction}

An author sometimes chooses words and arranges them in such a way that creates an aesthetic imagination-usually marked with connotative words (meaning not actually) and symbolic words or words that represent other meanings (Pradopo 2009:56). One poetic dictions is seen in the lyrics "pada mulutmu yang terkunci." This lyric certainly does not mean that the mouth is locked like a door, but what is meant here is the mouth that is covered with a mask or face shield. This meaning is appropriate because it fits the context when a pandemic occurs. Another poetic diction is in the phrase "jalan keterputusanmu" in the lyric "Tuhan itu ada pada jalan keterputasanmu". The meaning of "your path of severance" is the isolation of man in a secure place. This is connected with the next lyric, "Dengan Dunia yang berpenyakit," namely the viral external environment.

\section{Rhyme}

Rhyme is the regular repetition of the same sound in a poem. Rhyme is not only to show the aesthetics of sound but often the regularity of the sound 
represents a certain feeling and meaning of the poem. In the poem "Bubarnya Agama," the aesthetic aspect of sound is not emphasized too much. However, this poem also contains rhymes, namely the harmony of the " $i$ " vowel sound at the end of some lyrics.

\title{
Tone and Sense
}

\author{
Makkah sepi \\ Madinah sunyi \\ Kakbah dipagari \\ Pada mulutmu yang terkunci \\ Pada hakikat yang tersembunyi
}

The tone is a certain attitude made by the reader poet. The tone depicted in this poem is "advising" or "teaching." At the beginning of his poem, the poet describes the various impacts of the Coronavirus on the worship activities of Muslims. They are starting from the closing of Mecca and all houses of worship and the prohibition of worship together. Humans must worship in their respective places and not in mosques or other public places. But at the end of the poem, the poet tries to take lessons from all that. Thus, the atmosphere described in the poem "Bubarnya Agama" is solemn. The poet in this poem seems to be advising all humans regarding the ongoing Coronavirus pandemic as in religious forums.

\section{Metaphors}

Figurative language is often equated with figurative language, namely the style of language that illustrates or equates something with other things so that the picture of something is more interesting and lively (Pradopo 2009:62). The poem "Bubarnya Agama" found a personification figure of speech. Personification figure of speech is a figure that equates objects with humans (Pradopo 2009:75). This language style can be seen in the lyrics of "corona mengajarimu." Corona is an inanimate object, while intelligent beings can only do the nature of "teaching". Corona is characterized as a human being who teaches humans. The meaning of "corona teaches you" is that through the coronavirus pandemic, humans can take many lessons and lessons from it. Personification figure of speech is also seen in the lyrics "Dengan Dunia yang berpanyakit." The world is an inanimate object that can neither be sick nor healthy. Living beings can only feel the nature of "sickness and health." The meaning of the "diseased world" is that the Coronavirus that has hit most parts of the world makes the earth look as if it is sick.

\section{Message}

To find the message in this poem, it is necessary first to formulate the overall meaning of this poem. The poem "jalan keterputusanmu" is Said Muniruddin's response to the ongoing Coronavirus pandemic. Corona has had a significant impact on all aspects of human life, including religious activities. Mecca is quiet, Medina is quiet. All houses of worship were closed. Religious rituals, ranging from Hajj, Umrah, Friday, congregational prayers, and all religious activities allowed before the pandemic, after the Coronavirus came, everything became forbidden. All people must worship in their respective places away from the crowd. Even the sacred call to prayer changes according to the circumstances. The poet concludes that the religious activities carried out together and so freely seem to be useless. God is inviting people to worship in solitude. As khushu', it will be easier to be present in solitude than in a crowd. 
No one thought that in early 2020, this hidden enemy would come and destroy the fabric of human life. Corona came to leave a very scary sense of anxiety. Everyone shunned, all objects suspect. When everyone might hate this virus so much, the poet characterizes Corona as a teacher who teaches many religious matters. Mecca, Medina, Mosque, Kaaba, are religious symbols of approaching God. Corona comes with a lesson that worship is not only in that place and not only that. Prayer in the mosque is good, Hajj in Mecca is noble, but people often forget that the house also needs to be "prayed," and the Koran needs to be read. Many pursue righteousness outside the home but do not get along inside their homes. Many people regularly pray at the mosque, but the congregation never invites their own families. Corona rebukes people who prioritize major worship but forget about minor worship. Even in religion, the Qur'an clearly explains that before you improve others, improve yourself and your family (Q.S. AlTahrim (66): 6). Thus, the Coronavirus pandemic outwardly does a lot of harm, but on the other hand, it contains deep wisdom. The chaos in the worship of Muslims does not mean that Corona is dissolving religion but instead purifies that religion, namely by paralyzing the ritual crowd and forcing people to find God in silence and themselves. This poem closes with a conclusion that only Allah is in power. Nothing can match His power. God has the power to bring health and disease to this earth. Only Allah is eternal; other than Him will perish.

So naturally, human existence living in this world is to find Him in all realms of worship and that Allah is everywhere and at any time so that there is no reason for humans to neglect to worship Allah SWT. Humans are often too busy with the world to forget the afterlife, even though what humans are chasing after is just like the rain that grows plants and impresses farmers, then after some time, the plants turn yellow, dry, wither and crumble, as explained in verse QS al-Hadid(57):20 (Hizkil 2021:183). This is an important message that can be learned from this poem.

\section{Tradition Aspects/Extrinsic Elements}

As previously explained, what is meant by the aspect of tradition here is an element related to the historical creation of literary works. Although Said Muniruddin is a poet from Indonesia, the background for creating the poem "Bubarnya Agama" is the Coronavirus pandemic that is sweeping all parts of the world. In this poem, he addressed all Muslims around the world. This poem is included in religious poetry. This is by the author's background, who is also a religious person. Said Muniruddin, who was born on December 12, 1979, inherited the blood of artists as his brothers. His father, Said Ali bin Abdullah is an artist, poet, historian, and calligrapher (Muniruddin 2020). The religious and artistic values surround the poet's figure that also influences Said Muniruddin's works, and the poem "Bubarnya Agama" is no exception.

\section{Analysis of "Syukrān Kurūnā" Poem by Jabeer Ali Ba'adany}

The poem "Syukrān Kurūnā" was written by the Yemeni poet Jabber Ali Ba'adany. He wrote this poem on his Twitter account on March 15, 2020. he is a writer and writer. He has written several books; one of the most famous is Diwan which was published in 2019. This book contains a collection of poems that he wrote during his life. The following is an analysis of the poem "Syukrān Kurūnā" by Jabeer Ali Ba'adany (Ba'adany 2020) 


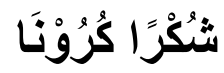

Oleh: Ali Jabeer Ba'adany

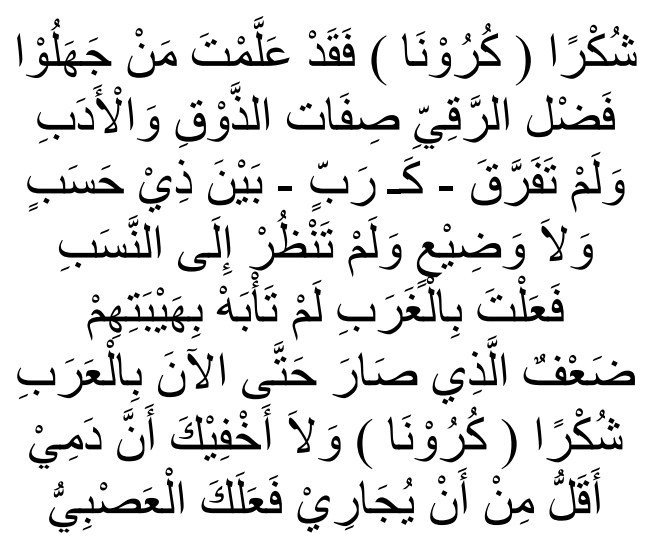

(Thank You Corona)

By: Ali Jabeer Ba'adany

Thank you (Corona); you teach those who are stupid

The virtue of sophistication, quality of taste, and morals

And you do not differentiate - as God does - between those who are worthy

The low (unworthy), you also do not see the lineage

You do it in the West; you don't care about their prestige

And the weakness that has happened so far in Arabia

Thank you, Corona, and I won't hide from you that my blood

Too little to pay for your great service

\section{Affinity Aspect/Intrinsic Element Theme}

\section{Theme}

This poem generally describes the poet's gratitude to the Coronavirus. Poets characterize the Coronavirus as a figure who positively impacts the order of life. The poet seems to put aside the negative effects of the Coronavirus and highlight the positive side. Corona awakens a lot and teaches people about the new, more modern, and civilized order of life. The poet characterizes Corona as a just figure (like God) because it reaches all parts of the world and is not indiscriminate. Thus, the writer concludes that the theme of this poem is justice and humanity.

\section{Diction}

An author often chooses words and arranges them in such a way as to create an aesthetic imagination. The study of badi' science is known as uslub Thibaq, namely the gathering of two lafadz which have opposite meanings in one sentence or speech (Wahbah 1984:232). This uslub can be seen in the following poetry lyrics:

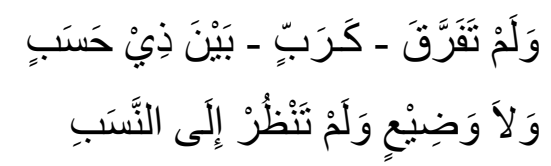




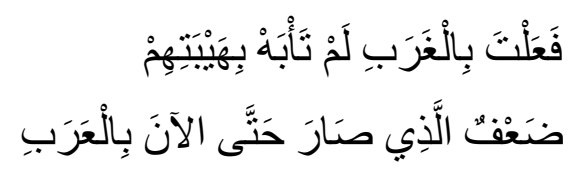

In the lyrics above, the poet describes Corona's justice, not distinguishing between

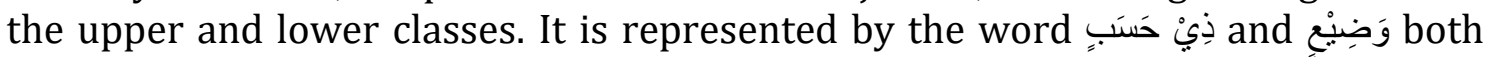
words have opposite meanings and come together in one utterance. In addition, the poet also mentions that Corona is present in the Western world and the Eastern world by using the word الغرب Although there is no explicit mention of the eastern world, the mention of the Arab region already represents it. Word العرب and الغرب opposite in meaning where the West region represents Europe and America, while the East region represents Asia and Africa. The East is often seen as colonized, left behind, and deprived of its independence, while the West is seen as a superpower region that colonizes and controls the East.

\section{Rhyme}

In the study of Arabic language and literature, especially in the science of balaghah, aspects of the beauty of language are included in the discussion of badi' science. Badi' science itself is the science of knowing the beauty aspects of a sentence or speech (Sayyid Al Hasyimi 2005:360). There is only one term in bad science, namely the similarity of the final letter in two or more sentences (Idris 2020:20). In the poem "Syukrān Kurūnā" there is only 'in the second lyric, namely the sound of harakat kasrah. Also, the kasratain sound in the third and fourth lyrics.

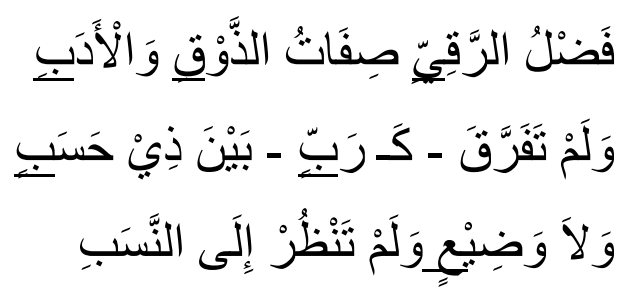

Saja' also seen the repetition of the vowel kasrah at the end of the second, fourth,

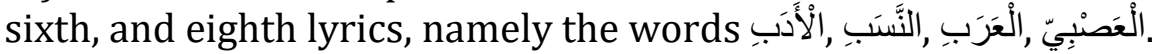

\section{Tone and Sense}

The atmosphere depicted in this poem is the poet's attitude who seems to be having a dialogue with Corona and thanking him. So that the tone that wakes up is that the poet positions himself as one of the communicants. But furthermore, the poet is giving an understanding to humanity that humans should be grateful to Corona because of the various wisdom for the Coronavirus pandemic. Everyone should obey the poet's attitude so that the Coronavirus pandemic is seen from the negative side and explores the positive side. Thus, the tone built from this poem is a tone of gratitude and advice.

\section{Metaphors}

One of the figures of speech in the poem "Syukrān Kurūnā" is the personification figure of speech, a metaphor that equates objects with humans. Personification metaphors in balagah science are often equated with isti'ârah makniyyah. However, the two have striking differences where isti'ârah makniyyah does not always put human nature on inanimate objects. Still, it can happen that 
the nature of an object is based on other objects or materials. Meanwhile, the personification figure of speech must describe inanimate objects or inanimate objects as human characteristics. This figure of personification or isti'ârah

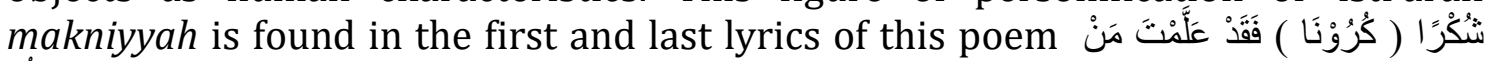
جَهَلُْو Corona is characterized as a teacher who teaches many things related to the new, modern, and moral order of life. The whole world has to adapt to this situation. Various forms of new technological innovations adapt to situations and conditions.

Massage

To find the message in this poem, it is necessary first to formulate the overall meaning. The poet at the beginning of his poem thanks Corona who has taught humans فَضْنُ الرَّفِيّي (preference for sophistication) The purpose of this sophistication is all forms of innovation in the field of technology that have emerged amid a pandemic. The emergence of Touchless Keypad and Immunotouch Wristband is proof of these technological innovations. Furthermore, Corona also teaches the importance of صِفَاتُ الذَّوقْ وَالْنَدَبَ (quality of taste and manners) the point is that the Corona pandemic fosters a sense of empathy between humans, considering that almost all humans feel the impact of this pandemic. All humans who feel it must have the spirit of cooperation so that the new normality that is being followed is also accompanied by new solidarity and morality.

The Coronavirus pandemic that attacks all countries indicates the justice of Corona. He attacks anyone and does not indiscriminately. He is present in Europe, America, Asia, Africa, and Australia. Corona is present in all parts of the world regardless of the prestige of each region. Poor-rich, young-old, king-people, advanced-developed, all attacked. The crisis caused by the Coronavirus has shocked all without exception, large countries and small countries. Corona reminds all countries of their inability to deal with an invisible virus. When the superpowers were competing to develop their defense equipment, Corona was here to rebuke all of them. The visible enemy may not defeat them, but they forget that invisible enemies will not be destroyed by simply relying on their defense equipment. Even the presence of Corona has changed national development priorities in every country. Thus, Corona comes to bring awareness and justice.

At the end of this poem, the poet again thanks Corona, and reveals that Corona's great service in bringing awareness and many changes also requires sacrifice. The poet says, "that my blood is too little to pay for your nervous act." From this, the poet considers that the causes of death worldwide due to the Coronavirus are human sacrifices for awareness and major changes in the world. Thus, the great message of this poem is that the Coronavirus pandemic that occurred brought a big positive impact on changes in the order of human life. It raises awareness of the importance of moving forward in life. He teaches an attitude of empathy, solidarity, and high mortality amid an even distribution of pandemics worldwide.

\section{Tradition Aspects/Extrinsic Elements}

Talking about the historical aspect of creating a literary work requires a biographical search of the author. The poem "Syukrān Kurūnā" was written by Jabber Ali Ba'adany, a Yemeni poet and author. He was born in 1980 AD. Even though he comes from Yemen, he lives in a superpower country, the United States 
of America. The creation of the poem "Syukrān Kurūnā" is closely related to the background of the poem and is domiciled. In his poetry, the poet alludes to the prevalence of pandemics in both Western and Eastern countries and alludes to the prestige of each region. Corona is present in all places without favoritism. This shows that the poet directly feels the impact of Corona where he is domiciled. America, which is famous for all its sophistication and progress, is also unable to fight the ferocity of the Coronavirus.

Analysis of the Similarities and Differences in Said Muniruddin's Poem "Bubarnya Agama” and "Syukrān Kurūnā" Poem by Jabeer Ali Ba'adany.

Comparative Literature Study of the two poems will reveal the relationship and differentiation of each poem. The existing relationship can be revealed by first analyzing the similarities between textual and contextual. The textual similarity can be seen from language style and other constructive elements. In contrast, the contextual similarity is seen from the background of the creation of the two and the message the author wants to convey through the poem. Poems from different countries will enrich the disclosure of the relationship between the two poems because each author with each poem has a different personal, social and cultural background.

The poem "Bubarnya Agama" and the poem "Syukrān Kurūnā" have different themes. The difference in this theme will determine the overall content and message. The poem "Bubarnya Agama" has the theme of divinity, while the poem "Syukrān Kurūnā" has the theme of humanity and justice. The poem "Bubarnya Agama" emphasizes the impact of the Coronavirus on the purity of Muslim religious activities so that by studying this poem, one will arrive at true piety to Allah by contemplating His power. The poem "Syukrān Kurūnā" emphasizes the impact of the Coronavirus on changing the order of human life that is more modern, empathetic, and moral. Corona is also present in all regions indiscriminately, which hints at justice

Studying two poems in different languages will show the peculiarities of the linguistic rules of each language, such as Arabic, which is closely related to balagah science. The two poems above each have a distinctive poetic diction. The poem "Bubarnya Agama" with the background of the Indonesian language and author contains several poetic dictions, including your locked mouth, your broken path, and a diseased world. These poetic dictions refer to the conditions experienced by all human beings when they have to continue to carry out worldly activities and worship in a world condition that is "diseased" The poem "Syukrān Kurūnā," with an Arabic language background and author, presents the peculiarities of Arabic poetry in the framework of balagah science, one of which is uslub Thibaq. This language style is found in the word ذَبِي حَسَبِ and وَضِيْع as well as العرب and الغرب and The club is understood as a style of language that presents two contradictory things in one presentation. These words represent the justice of Allah SWT through his creature named Corona, who is present and afflicts all regions and circles.

The peculiarity of the two poems is not only from the elements of their respective themes and poetic diction but also from other elements in terms of rhyme; for example, the two poems both contain rhyme, although they are not too dominant. Rhyme is generally used for poetry, but Arabic poetry generally only uses the saja' term. The repetition of the vowel " $\mathrm{i}$ " in some of the poem's lyrics 
"Bubarnya Agama" is evidence of the harmony of sound in the poem. As for the poem "Thank You Corona" the repetition of kasrah and kasratain in some of the lyrics is characteristic of Arabic poetry, which adds to its poeticity. The vowel sound "i" and the sound of kasrah and kasratain are one unit. All three are grouped in the low sound because the sound is born from lowering the lower lip. The low sound in the study of poetry is often interpreted as a condition that indicates a sad or depressed state experienced by the poet. According to the author, this is by the sad and downturn that the Coronavirus presents.

One more thing that should not be missed is the figurative language style of the two poems. Both Indonesian and Arabic, have this style of language. Both poems contain personification or, in the science of balagah isti'ärah makniyyah. Both characterize Corona as a "figure" who teaches humans many things. The poem "Bubarnya Agama" characterizes Corona who purifies religion. In contrast, the poem "Syukrān Kurūnā" characterizes Corona as a fair figure and makes people aware of the importance of modernity and morality.

Despite having many similarities in the content of the two elements, each poem still carries its uniqueness as a poem from a different language and country, not least in terms of its message. The poem "Bubarnya Agama" conveys that the chaos of Muslim worship does not mean that Corona is dissolving religion but instead purifies religion by paralyzing the ritual crowd and forcing people to find God in silence and themselves. Only Allah is eternal; other than Him will perish. So naturally, human existence living in this world is to find Him in all areas of worship and that Allah is everywhere and at any time so that there is no reason for humans to neglect to worship Allah SWT. Meanwhile, the poem "Syukrān Kurūnā" conveys the message that the Coronavirus pandemic that has occurred has had a major positive impact on changes in the order of human life. It raises awareness of the importance of moving forward in life. He teaches an attitude of empathy and high mortality amid an even distribution of pandemics worldwide.

Although the poem "Bubarnya Agama" and "Syukrān Kurūnā" contain their characteristics, they both have the same context of the discussion, namely the Coronavirus pandemic. This is the thing that connects the two. These two poems are a response from the two authors to the crisis of the Coronavirus pandemic that is sweeping the world. However, the differences in the backgrounds of the two poets determine their perspective on the Coronavirus. Said Muniruddin is a writer from Indonesia who is also a religious person who views Corona from a religious point of view. Meanwhile, Jabber Ali Ba'adany is a writer from Yemen who works daily in the United States, viewing Corona's influence on the order of life in the Eastern and Western hemispheres. Although he is from Yemen, because he is domiciled in the United States, then in his poetry, he alludes to both, although not explicitly.

\section{CONCLUSION}

Said Muniruddin's poem "Bubarnya Agama" by Said Muniruddin from Indonesia and the poem "Syukrān Kurūnā" by Jabeer Ali Ba'adany from Yemen are two poems that have their characteristics in terms of their intrinsic and extrinsic elements. The poem "Bubarnya Agama" by Said Muniruddin from Indonesia carries the message that the chaos of Muslim worship does not mean that Corona 
is dissolving religion but instead purifies religion. God is sovereign, and only God is eternal. So naturally, human existence in this world is to find Him in all areas of worship and that Allah is everywhere and at any time. Furthermore, the poem "Syukrān Kurūnā" by Jabeer Ali Ba'adany from Yemen conveys the message that Corona positively impacts the order of human life. He raises awareness of the importance of moving forward in life and teaches solidarity and high mortality amid an even distribution of pandemics worldwide.

From the perspective of Comparative Literature studies, it can be concluded that the poems "Bubarnya Agama" and "Syukrān Kurūnā" are two poems that are the responses of two poets from different countries to the Coronavirus pandemic that is sweeping all parts of the world. The differences in origin, domicile, and environment of each author also determine their perspective on the coronavirus pandemic that occurred. The two poems are connected with the common perception of their authors that Corona is a "figure" who brings wisdom and major changes to the living and religious order of humanity. The two poets, with their poems, both give a message to all of humanity to stay strong and optimistic in facing the Coronavirus pandemic that is happening.

The author believes that these two poems are only a small part of the many literary works born amid the current global pandemic, so further studies or similar are expected to continue to exist and live to contribute to the moral conception of all human beings.

\section{REFERENCE}

Andriyani. 2021. "Wabah Corona Dan Unggahan Di Instagram: Analisis Komponen Tindak Tutur." Journal of Culture, Arts, Literature, and Linguistics 7(1):1527. doi: http://dx.doi.org/10.30872/calls.v6i2.3715.

Ba'adany, Ali Jabeer. 2020. "شكر ا كرونا." Retrieved (https://twitter.com/badanigabr/status/1241619688687161344).

Dirman, R. 2019. "Analisis Struktur Puisi Dalam Kumpulan Puisi 'Aku Ini Binatang Jalang' Karya Chairil Anwar.” Jurnal Bastra 4(2):331-40. doi: http://dx.doi.org/10.36709/jb.v4i2.10743.

Elyusra. 2020. “Estetika Dan Makna Dalam Puisi 'Untuk Corona Tanpa Mengeluh' Karya Salami Dan Implikasinya Terhadap Pembelajaran Di Sekolah." Jurnal Lateralisasi: Jurnal Bahasa Dan Sastra Indonesia 8(2):1-13. doi: https://doi.org/10.36085/lateralisasi.v8i2.1251.

Fananie, Zainuddin. 2011. Telaah Sastra. Surakarta: Muhammadiyah University Press.

Hassan, Hakim Abdul. 1983. "Al-Adāb Al-Muqāran Bina Al-Mafhūmain Al-Faransiy Wa Al-Amrīkiy." Fushul, Majalah Kritik Sastra 1(3).

Herwan. 2021. "Citraan Metafor Pada Puisi Tema Covid-19 Karya Anak Sekolah Dasar." Dialogsa: Jurnal Kajian Bahasa, Sastra, Dan Pengajarannya 3(4):403-10. doi: . https://doi.org/10.30872/diglosia.v3i4.140.

Hilal, Muhammad Ghanimi. 2003. Al-Adāb Al-Muqāran. Kairo: Nahḍatu Mișra. 
Hilmy, Masdar, and Khoirun Niam. 2020. "Winning The Battle of Authorities: The Muslim Disputes Over The Covid-19 Pandemic Plague in Contemporary Indonesia." Qudus International Journal of Islamic Studies (QIJIS 8(2):293326. doi: http://dx.doi.org/10.21043/qijis.v8i2.7670.

Hizkil, Ahmad. 2021. "Hakikat Kehidupan Dunia Dalam Q.S. Al Hadid (57):20 (Analisis Pembacaan Heuristik Dan Hermeneutik Michael Riffaterre)." AlIrfan: Journal of Arabic Literature and Islamic Studies 4(2):170-85.

Hosillos, Lucia V. 2001. Sfera Konsentrik Dalam Kesusastraan Bandingan. Kuala Lumpur: Dewan Bahasa dan Pustaka.

Hutomo, Saripan Sadi. 1993. Merambah Matahari: Sastra Dalam Perbandingan. Jakarta: Gaya Masa.

Idris, Mardjoko. 2020. Ilmu Badi', Kajian Keindahan Berbahasa. Yogyakarta: Penerbit Karya Media.

Muniruddin, Said. 2020. "Bubarnya Agama." Retrieved (https://saidmuniruddin.com/2020/03/16/bubarnya-agama/).

Nada, Thaha. 1980. Al-Adāb Al-Muqāran. Beirut: Dār al-Ma'ārif.

Nivak, John Guruh. 2021. "Moralitas Dalam Puisi-Puisi Bertopik Covid-19: Pendekatan Filsafat Sastra(Filsafat Etika Immanuel Kant)." Universitas Sarjanawiyata Tamansiswa Yogyakarta.

Pradopo, Rachmat Djoko. 2009. Pengkajian Puisi. Yogyakarta: Gadjah Mada University Press.

Pribadi, Muhammad. 2011. "Qasīda Banāt Su'ād Li-Ka'b Ibn Zuhayr Ibn Abī Salmā: Tahlīl Al-Uslūb Al-Adabī.” Al Jami'ah: Journal of Islamic Studies 49(1):199229. doi: https://doi.org/10.14421/ajis.2011.491.199-229.

Rahim, Raid Abdul. 2010. "Risalatu An-Naba 'an Al-Waba Lizainiddin Ibn Al-Wardi (Dirasah Naqdiyyah)." Jāmi'ah al-Najah al-Wathaniyyah.

Rahmani, Ady Fauzi. 2010. "Risalatu An-Naba 'an Al-Waba Lizainiddin Ibn AlWardi (Dirasah Naqdiyyah)." Jāmi'ah al-Najah al-Wathaniyyah Palestina.

Ratna, Nyoman Kutha. 2015. Teori, Metode, Dan Teknik Penelitian Sastra. Yogyakarta: Pustaka Pelajar.

Sarhan, Samir. 1983. “'Mafhūm Al-Ta`sīr Fìal-Adab Al-Muqāran’Dalam Al-Adab AlMuqāran.” Fushul, Majalah Kritik Sastra 3(3).

Sayyid Al Hasyimi. 2005. Jawāhir Balāghah. Libanon: Dār Al Ma'rifah.

Tasnimah, Tatik Maryatut. 2010. “Menelisik Kosmopolitanisme Sastra Arab (Kajian Sastra Banding).” Adabiyyāt: Jurnal Bahasa Dan Sastra 9(1):1-20. doi: DOI:10.14421/ajbs.2010.09101.

Thahhan, Raymun. 1972. Al-Adāb Al-Muqāran Wa Al-Adāb Al-'Ām. Beirut: Dār alKitāb al-Lubnāni.

Wahbah, Majdi. 1984. Mu'jamul Mustalahat Al-Arabiyyah Fi Al-Lughah Wa Al-Adab. 
Beirut: Maktabah Lubnan.

\section{COPYRIGHT NOTICE}

Authors retain copyright and grant the journal right of first publication with the work simultaneously licensed under a Creative Commons Attribution 4.0 International License that allows others to share the work with an acknowledgement of the work's authorship and initial publication in this journal.

(c) (†) 
HALAMAN INI SENGAJA DIKOSONGKAN

Jurnal Ilmiah Program Studi Pendidikan Bahasa Arab IAIN Palangka Raya Vol. 9, No. 2 /187-204 Al-Ta'rib | p-ISSN 2354-5887 | e-ISSN 2655-5867 